\title{
Resource Availability and Distribution in Public and Private Special Education Schools in Cross River State, Nigeria
}

\author{
Peter James Ntukidem \\ Department of Educational Administration and Planning \\ University of Calabar, Calabar, Nigeria
}

Tel: 234-803-672-2006 E-mail: pan4world@yahoo.com

Eno Peter Ntukidem

Department of Vocational and Special Education

University of Calabar, Calabar, Nigeria

Tel: 234-802-353-6810

Eno Etudor Eyo

Department of Curriculum Studies and Educational Management

University of Uyo, Uyo, Nigeria

Tel: 234-802-543-1187

Received: January 24, 2011 Accepted: February 14, 2011 doi:10.5539/ies.v4n3p119

\begin{abstract}
This study investigated the availability and distribution of staff and facilities/equipment in private and public special needs schools in Cross River State. Sixty-nine (69) teachers and three (3) principals of these schools constituted the sample size of the study. One hypothesis and one research question were postulated to guide the study. The instrument used for data collection was Document Survey for Special Needs Persons Questionnaire (DSSNPQ). The data was analyzed using frequency counts and chi square statistical analysis. The findings revealed that there was no significant difference between the distribution of teaching staff in public and private schools, more facilities/equipment were available in private schools than in public schools. It is therefore recommended that the private sectors, non-governmental organizations and industrial organizations be involved in providing for the needs of exceptional individuals both in public and private schools.
\end{abstract}

Keywords: Resource availability, Resource distribution, Special education schools

\section{Introduction}

Education has been generally recognized as an instrument par excellent for national development (Federal Republic of Nigeria (FRN), 2004). The national development here includes both the physical and human development. Within that human development, those with special needs are not excluded. This gave impetus to the FRN (2004) to include in her national policy on education special education to provide for children with special needs in order to:

(a) Give concrete meaning to the idea of equalizing educational opportunities for all children, their physical, sensory, mental, psychological or emotional disabilities not withstanding;

(b) Provide adequate education for all people with special needs in order that they may fully contribute their own quota to the development of the nation;

(c) Provide opportunities for exceptionally gifted and talented children to develop their talents, natural endowments/traits at their own pace in the interest of the nation's economic and technological development;

(d) Design a diversified and appropriate curriculum for all the beneficiaries (p.48).

From the foregoing, one may be interested to know who children with special needs are. In the National Policy on Education, they are those who have learning difficulty because of different sorts of handicaps: blindness, partial sightedness, deafness, hardness of hearing, mental retardation, social maladjustment, physical handicap, etc. due to 
circumstances of birth, inheritance, social position, mental and physical health, or accident in later life. There are also the specially gifted children who are intellectually precocious and find themselves insufficiently challenged by the programme of the normal school and who may take to stubbornness and apathy in resistance to it (FRN, 1981:36). These individuals demand special administrative models (for example, special administrators, special staffing, facilities and funding). In general terms, services rendered to the special needs learners are expected to be specially designed and delivered by highly trained and specialized personnel.

There are some special schools established to cater for these individual besides the integrated or inclusive educational setting. Some of them are public while others are private. Critically looking at the two groups, disparity exists both in their administrative models and service delivery. Although administrative models according to Edem (2003) include planning, organizing, staffing, directing, co-ordinating which embodies supervising, reporting and budgeting; in this study, emphasis is laid on staffing, supervising and budgeting.

Staffing explains how the administrators arrange for the regular supply of personnel, staff training through workshops, seminars, teachers' meetings and conferences, interest study groups, exchange visits, classroom visits and demonstration lessons in order to meet the needs of special needs individuals. Mbipom (2000) sees staffing as the procedure through which the regular employment of the proper kind and number of staff necessary to accomplish the goals of the school or organization is achieved. Thus, the morale of the staff in the school will be raised for higher productivity. Supervising refers to monitoring and coordinating the activities, facilities and personnel at various units of the special school. It entails also, provision of corrective measures and positive criticisms instead of judgment so as to achieve the set goals of building those special needs. Budgeting embodies fiscal management, financial planning and control by administrators in order to ensure that the available financial resources is not diverted from the original intentions of providing special facilities, equipment, environment, medical care, consultation services, clinics, among other things, for the exceptional or special needs individuals.

In a study carried out by Fabunmi (2000) on the management of special education resources in Ibadan, the results revealed that special education resources were not adequate in schools. They were not evenly distributed and the few available resources were not efficiently used, while others were often diverted to normal students. Ikpaya (2000) has also noted that special schools or centres managed by private individuals or religious bodies provide better services than those established by government.

However, the study of Abosi (1999) showed that, the individuals with special needs are not well catered for by the government. He lamented that teachers' training and general development, for those with special needs is really lacking, especially in Africa. Furthermore, he emphasized that planning, organizing and management of special education has been characterized by poor vision and commitment, inadequate funding, selfish interest among experts and negative attitudes as a result of negative African values, tradition and culture. These, among other things have influenced the proper delivery of services in form of rehabilitation, teaching, consultative services, provision of quantity and quality teachers, to mention a few. It is on this background that this study is conducted to compare the availability of material resources and staff distribution in public and private special education schools in Cross River State, Nigeria.

\section{Methods}

This study is explorative in nature. The population included all the three (3) principals and sixty-nine (69) teachers in all the special schools in Cross River State. The study made use of all the schools in the population which include Good Shepherd School for special education Ogoja, St. Joseph's school for the visually handicapped, Obudu and Ministry of Education special education center, old Ikang Road, Calabar, all in Cross River State. The first two are owned by private organizations and the later by the government. Hence, three (3) principals and sixty-nine (69) teachers constituted the subjects for this study.

The instrument used for this study was the researchers' developed questionnaire called Document Survey for Special Needs Persons Questionnaire (DSSNPQ). The instrument was made up of two sections. Section A dealt with demographic variables such as name of school, sex and academic qualifications. Section B was designed to elicit information on the availability of facilities in each school studied. The facilities varied from those for the hearing impaired, visually impaired, physically impaired, recreation and other relevant general equipment.

The instrument was subjected to scrutiny by experts in special education and measurement and evaluation. Suggestions and corrections of the experts were incorporated in the final version of the instrument. This process ensured the face and content validity of the instrument.

\section{Hypothesis}

There is no significant difference between the distribution of teaching staff in public and private schools. 


\section{Research Question}

What proportion/percentage of the facilities available in the state are located in public or private schools?

\section{Results}

Hypothesis: There is no significant difference between distribution of teaching staff in public and private schools.

Table 1 shows that the distribution of teaching staff in public and private schools are not significantly different $\left(\mathrm{x}^{2}=\right.$ $0.50 ; \mathrm{p}<0.05$ ). This means that the teaching staff in public and private schools in Cross River State is not significantly different. By this result, it implies that the distribution of teaching staff in special schools in Cross River State is seemingly the same both at public and private levels.

Research question: What proportion/percentage of the facilities available in the state are located in public or private schools?

Data in Table 2 shows that prostheses, electronic wheel chair, braces, artificial limbs and electrical typewriters are not available for the physically impaired neither in public nor private schools. Manual wheel chair is provided in public $(20 \%)$ and private $(80 \%)$ while crutches are provided in only private schools $(100 \%)$.

In Table 3, it is realized that facilities like Braille books, talking book, optacon, electronic calculators, reading computer machine, guide dogs are not provided for the visually impaired, neither in public nor private school. It is equally evident that, both public and private schools are able to provide typewriters (public $=12.5 \%$; private $=87.5 \%$ ), and audio tape (public $=25 \%$; private $=75 \%$ ). The greater number of typewriters and audio tapes were provided for the visually impaired by the private schools.

In Table 4, it is revealed that neither public nor private schools for the special needs individuals provides opaque projector, computer machines, and cubicles with chairs for the special needs persons. While both of them provide radio sets (public 57.1\%; private $42.9 \%$ ); television (public 25\%, private $75 \%$ ); and classrooms (Public $21.4 \%$, private $78.6 \%)$. It is shown also that only the private schools could provide overhead projector (100\%) magnifiers $(4.08 \%)$ and library $(100 \%)$ for the special needs persons.

It is shown from Table 5 that the public schools for the specials needs persons could provide 1 (33.3\%) football field, while private school could provide $2(66.7 \%)$. For lawn tennis court and handball pitch, neither of the school type provides for the exceptional persons.

\section{Discussion and Recommendations}

From the findings on the availability of facilities/equipment in public and private schools for the special needs persons, it is worth saying that, the special needs persons in private schools are more privileged of available facilities/equipment than those in the public schools. In terms of teaching staff, there was no significant difference between the distribution of teaching staff in the public and private special schools in Cross River State. The foregoing could be linked up to the kind of administrative models applied in each school type. For example, staffing, as was explained by Edem (2003) depends on how administrators arrange for the regular supply of personnel, staff training through workshops, seminars, teachers' meetings and conferences, interest in study groups, exchange visits, classroom visits and demonstration lessons. Consequently, if an administrator adopts a leadership style that does not see the need of arranging for the regular supply of personnel and their professional growth, it might result at limited number of staff. But if it is otherwise, the number with quality and efficiency would increase and unlimited knowledge would be available for the special needs individuals.

However, more teaching staff was recorded for the private schools. Also, looking critically at the general school system, it would be wise to say that more work is done by those teachers. This could be attributed to their being conscientious, closely supervised, specially trained, and committed hence, their competency to meet the needs of the special needs persons whereas in the public school, majority of them may not be specially trained for the exceptional persons. Some teachers are posted there by some political influence and other personal interest, and not for the sake of the students. The result has provided empirical support to Abosi (1999) findings that persons with special needs are not well catered for by the government.

Furthermore, the private schools being what it is seems to receive attention from private organizations, non-governmental organizations (NGOs), churches, communities and individuals, hence the more facilities. Besides, the administrative leadership style in the private schools is such that allows close monitoring and supervision of both human and material resources available in the school, such that anything provided is well cared for and properly maintained. A similar observation was made by Ikpaya (2000), who noted that special schools/centres managed by private individuals provide better services than those established by the government. In the public schools, it is almost the government alone the supplies the funds and other facilities, while the employed administrator does the 
administration. Well, these facilities/equipment are sometimes misused by certain individuals with the mind, "after all they are owned by the government" or "they are government properties". The finance provided may equally be diverted from taking care of the special needs individuals to something else. This is in consonance with the findings of Fabunmi (2000) that special education resources were not evenly distributed and the few available not efficiently used while others were diverted to non relevant activities.

However, there is a need for all hands to be on deck in providing for persons with special needs. It is therefore recommended that funding, facilities and other equipment, be it for the public or private schools, should be jointly provided for by the government, private sectors, local communities, non-governmental organizations, individuals, petroleum and industrial organizations.

\section{References}

Abosi, C. O. (1999). Trends and issues in special education in Botswana. The Journal of Special Education, 33 (1), $18-21$

Edem, D. A. (2003). Introduction to educational administration in Nigeria. Ibadan: Spectrum Books Limited.

Federal Republic of Nigeria. (2004). National policy on education. Lagos: Federal Ministry of Education.

Federal Republic of Nigeria. (1981). National policy on education. Lagos: Federal Ministry of Education.

Fabunmi, M. (2000). Management of special education resources in Ibadan North LGA, Oyo State, Nigeria. The Exceptional Child, 4(1), 52-54

Ikpaya, B. O. (2000). Issues on effective administration of special education in Nigeria. The exceptional child, 4 (1), $1-3$

Mbipom, G. (2000). Educational administration and planning. Calabar: University of Calabar Press.

Table 1. Chi square $\left(\mathrm{x}^{2}\right)$ test of teaching staff distribution in special schools in Cross River State.

\begin{tabular}{cccc}
\hline School & $\mathbf{N}$ & $\mathbf{\%}$ & $\mathbf{x}^{\mathbf{2}}$ \\
\hline Public & 33 & 45.8 & \\
Private & 39 & 54.2 & 0.50 \\
Total & 72 & 100.00 &
\end{tabular}

Not significant at 0.05 level; $\mathrm{df}=1, \mathrm{x}^{2}=3.84$

Table 2. Distribution of facilities/equipment for the physically impaired in public and private special school in Cross River State.

\begin{tabular}{clcccccc}
\hline S/n & Facility/equipment & \multicolumn{2}{c}{ Public } & \multicolumn{2}{c}{ Private } & \multicolumn{2}{c}{ Total } \\
\hline & & Freq & Perc & Freq & Perc & Freq & Perc \\
\hline 1 & Protheses & - & - & - & - & & \\
2 & Electronic wheel chair & - & - & - & - & & \\
3 & Manual wheel chair & 2 & 20 & 8 & 80 & 10 & 100 \\
4 & Braces & - & - & - & - & & \\
5 & Artificial limbs & - & - & - & - & & \\
6 & Crutches & - & - & 7 & 100 & 7 & 100 \\
7 & Electrical typewriters & - & - & - & - & & \\
\hline
\end{tabular}


Table 3. Distribution of facilities/equipment for the visually impaired in public and private special schools in Cross river State.

\begin{tabular}{clcccccc}
\hline S/n & \multicolumn{1}{c}{ Facility/equipment } & \multicolumn{2}{c}{ Public } & \multicolumn{2}{c}{ Private } & \multicolumn{2}{c}{ Total } \\
\hline & & Freq & Perc & Freq & Perc & Freq & Perc \\
\hline 1 & Braille machine & - & - & 16 & 100 & 16 & 100 \\
2 & Braille duplicator & - & - & 2 & 100 & 2 & 100 \\
3 & Braille books & - & - & - & - & - & - \\
4 & Typewriters & 2 & 12.5 & 14 & 87.5 & 16 & 100 \\
5 & Talking book & - & - & - & - & - & - \\
6 & Abacus & - & - & 2 & 100 & 2 & 100 \\
7 & Taylor frame & - & - & 2 & 100 & 2 & 100 \\
8 & Snellen chart & - & - & 1 & 100 & 1 & 100 \\
9 & Optacon & - & - & - & - & - & - \\
10 & Electronic calculators & - & - & - & - & - & - \\
11 & Canes & - & - & 3 & 100 & 3 & 100 \\
12 & Reading computer machine & - & - & - & - & - & - \\
13 & Thermoform machine & - & - & 2 & 100 & 2 & 100 \\
14 & Audio-tape & 1 & 25 & 3 & 75 & 4 & 100 \\
15 & Guide dogs & - & - & - & - & - & - \\
16 & Talking calculator & 1 & 100 & - & - & 1 & 100 \\
\hline
\end{tabular}

Table 4. Distribution of general relevant facilities and equipment for the special needs persons.

\begin{tabular}{clcccccc}
\hline S/n & Facility/equipment & \multicolumn{2}{c}{ Public } & \multicolumn{2}{c}{ Private } & \multicolumn{2}{c}{ Total } \\
\hline & & Freq & Perc & Freq & Perc & Freq & Perc \\
\hline 1 & Radio sets & 4 & 57.1 & 3 & 42.9 & 7 & 100 \\
2 & Television sets & 1 & 25 & 3 & 75 & 4 & 100 \\
3 & Overhead projector & 1 & 2.04 & - & - & - & - \\
4 & Opaque projector & - & - & - & - & - & - \\
5 & Computer machines & - & - & - & - & - & - \\
6 & Cubicles with chairs & - & - & - & - & - & - \\
7 & Magnifiers & - & - & 2 & 100 & 2 & 100 \\
8 & Laboratories & - & - & - & - & - & - \\
9 & Library & - & - & 1 & 100 & 1 & 100 \\
10 & Classrooms & 6 & 21.4 & 22 & 78.6 & 28 & 100 \\
\hline
\end{tabular}

Table 5. Distribution of recreational facilities for the special needs persons.

\begin{tabular}{clcccccc}
\hline S/n & Facility/equipment & \multicolumn{2}{c}{ Public } & \multicolumn{2}{c}{ Private } & \multicolumn{2}{c}{ Total } \\
\hline & & Freq & Perc & Freq & Perc & Freq & Perc \\
\hline 1 & Football & 1 & 33.3 & 2 & 66.7 & 3 & 100 \\
2 & Lawn tennis court & - & - & - & - & & \\
3 & Volleyball court & - & - & - & - & - & - \\
4 & Handball pitch & - & - & - & - & - & - \\
\hline
\end{tabular}

